\title{
LINKING METAPHORS AND ARGUMENTS TO SEMANTIC PROSODIES: A CASE STUDY OF VICTORY VERBS IN INDONESIAN ONLINE FOOTBALL NEWS
}

\author{
Prihantoro \\ prihantoro2001@yahoo.com \\ English Department, Faculty of Humanities, Diponegoro \\ University, Indonesia
}

\begin{abstract}
The use of hyperbolic victory verbs such as menghancurkan 'to destroy', menekuk 'to fold', menggunduli 'to shave bald' characterizes football news report in Indonesia. These verbs are used in the specific domain; therefore, suggesting that they need further examination. The objectives of this research are 1) to map metaphor classes and the arguments of these verbs and 2) to confirm whether the metaphor classes and the arguments are determinant to the semantic prosody of these verbs. Texts under football domainthat contain victory verbs were collected from different online news portals. The examination of victory verbs resulted on 10 affix formations and 10 different metaphor classes. Of these victory verbs, the frequent semantic roles are <agent> (the victors), <patient> (the defeated teams) and 〈theme> (the victories). The identification of the semantic prosody has shown that affix formation is fairly distributed and not significantly correlate to prosody. However, there is a strong tendency that metaphor class with negative nuance (like +DESTRUCTION, +WAR, +FIGHT) and the presence of an argument that takes <patient> semantic role suggests negative semantic prosody. They might be major cues to prosody in this data, but reexamination on a terminal level is still required to formalize this description, as some exceptions and irregularities are also present.
\end{abstract}

Key words: Indonesian football news, victory verbs, metaphor classes, semantic prosodies, semantic roles 
Abstrak: Penggunaan verba-verba hiperbolik yang menunjukan kemenangan seperti 'menghancurkan', 'menekuk' atau 'menggunduli' adalah salah satu karakteristik berita sepakbola di Indonesia. Kata-kata yang sifatnya spesifik ini patut untuk diteliti lebih lanjut dalam penelitian ini. Tujuan dari penelitian ini adalah 1) memetakan kategori metafora besrta argument pada verba kemenangan dalam domain sepakbola, 2) mengkonformasi apakah kategori metafora dan argument merupakan penentu prosodi semantic verba-verba ini. Teks dikumpulkan dari beberapa portal berita online. Hasil pengamatan verba kemenangan menunjukan ada 10 formasi afiks dan 10 kategori metafora. Argumen yang sering muncul pada verba-verba ini adalah <agen> pemenang, <penderita> pecundang, dan <tema> kemenangan. Hasil dari identifikasi semantic prosodi menunjukan bahwa formasi afiks bukanlah penentu prosodi karena terdistribusi secara rata. Namun demikian, ada korelasi yang kuat antara jenis metafora, prosodi negative (seperti +PENGHANCURAN, +PERANG, +PERTIKAIAN). Kehadiran argument dengan tipe <penderita> memperkuat prosodi semantic negatif. Aspek-aspek tadi merupakan determinan yang sangat berpengaruh dalam pencirian prosodi semantic negatif. Meski demikian, pengujian dan formalisasi pada level akhir, yaitu leksis, karena ada potensi iregularitas dan pengecualian.

Kata kunci: berita sepakbola Indonesia, verba kemenangan, kategori metafora, prosodi semantic, peran semantik

\section{INTRODUCTION}

Victory verbs are defined as a set of verb that is used to indicate that a team is victorious. Sport is the domain where these verbs are frequently in use. In English, words like 'to defeat', 'to win' or 'to champion' fall to the category of these verbs. The goal of this paper is mapping the victory verbs to different metaphor classes and identifying the semantic prosody that each verb carries. By understanding the semantic prosody, we will later be able to understand whether victory verbs in football news have the tendency to lean towards positive or negative semantic prosody. In this paper, the affix formation and semantic roles of the verbs argument are described. Whether they are related to the verbs' prosody is also investigated.

Before further reading, it is important to realize that this study is performed under metaphoric framework. Hence, some of the data might be translated literally to understand how target words are used metaphorically. 
In football news columns, hyperbolic words are often used. Bergh \& Ohlander (2012) as well as Lewandowski (2012) believe that this is one of the features of language used in football domain. The words seem to violate selectional restriction, readers, however, seem to accept this very well and have no difficulty in identifying the reference(s). Consider (1) and (2):

(1) Juara La Liga musim lalu Atletico Madrid mendapatkan amunisi baru di lini pertahanan

La Liga champion last season, Atletico Madrid will get a news defensive amunitions

(2) Sturridge belum 100 persen fit jadi akan bagus jika menyimpannya sebagai senjata pamungkas

Sturridge is not 100 percent ready so it would be good to keep him as an ultimate weapon

In the sample above, (1) it is reported that Atletico Madrid has managed to buy a new defensive player. The player here is presented as amunisi 'amunitions'. In (2), one of the team members, Daniel Sturridge, is reported to be unprepared and it would be useful to keep him on reserve. She is referred here as senjata pamungkas 'an ultimate weapon'. "amunitions" and "ultimate weapon" are +WAR terms used in +FOOTBALL domain and are, thus, acceptable in this domain because they are frequent metaphors. The [+UPPERCASE] symbol is used to mark conceptual domain. It will be used throughout the paper. As for arguments/roles, they are marked by these brackets $\langle>$.

\section{LITERATURE REVIEW}

Kovesces (2010) believes that metaphor can be defined as understanding one conceptual domain in terms of another conceptual domain. Here +FOOTBALL is the source domain, while the target domain is +WAR. The use of +WAR metaphors in football news domain is not something new. For this reason, the violation of selectional restriction seems acceptable as the semantic feature of the target domain is transferred to the source domain. This allows readers to tolerate the use of inanimate features such as munitions, weapons, or other war terms, to refer to football players that have the feature of animate. 
Back in 2004, Charteris-Black published the result of a metaphor study by a corpus approach. In the book, he investigated metaphors in different domains, and in sports, +WAR metaphor is noted as one of the most frequently used metaphors in sports (Charteris-Black, 2004, p. 122). Bergh (2011) conducted a more specific study with a more provocative title: Football is War.

Physical aggression in football (mostly from fans, but also from team members) is a common phenomena as observed by Russel (2008), but whether this is determinant in the use of +WAR metaphor in football needs further investigation. Although some studies show that +WAR metaphors are a common phenomena, Lewandowski (2009) has shown that at least in Polish, non-violent metaphors are also used in football articles. At this point, Lewandowski work Football is not Only War (2012) seems to complement Bergh's Football is War (2011). On the other hand, Spandler, et al. (2014) studied metaphors from the applied science perspective, and commented on how football metaphors are used to assist therapy. But this is beyond the scope of this research.

There have been some studies about metaphors in Indonesian football news. Khairina (2012) listed some metaphors that are unique to Indonesian and German via a comparative study. Metaphor of +WAR was also listed here. Later we will see how the categorization may differ orcomplement this study. Prayogi (2013) claimed to describe conceptual, structure and ontological metaphors as related to this topic, but the data is quite scarce. Lestari (2013) investigated football articles under dysphemism framework. From the framework, we understand that she focused on negative prosody words. This study will reveal whether positive prosody is also present. Wardani (2014) focused her metaphor study on nouns. As for this study, it is focused on verbs. However, as verb arguments take crucial roles, they are also included in the analysis.

As for semantic prosody, it is a term that refers to the positive ornegative nuance projected by a word. There has been some intense discussion on this topic. To my knowledge, Hunston (2007) was the most recent work that revisited this topic. This phenomenon has been known by many names, such as polarity analysis or sentiment analysis in computer science. I, here, prefer to use semantic prosody as this term is widely used in works following corpus linguistics tradition. On the application level, Prihantoro (2015) recently worked on the semantic prosody of Indonesian words of effect (conjunctions), 
and the data is obtained from BPPT corpus (Adriani \& Hamam, 2009), a corpus with four different domains. This research is different, as it will focus on victory verbs under one specialized sub-domain: football news, which is under sport domain.

\section{METHODOLOGY}

In this research, I employed Metaphor Identification Procedure (MIP) to recognize victory verbs. The procedure begins by full text reading, and proceeds to determine the lexical unit(s) to investigate. Left and right context are analyzed and basic contemporary meaning is defined (e.g +VISION, +BODY PARTS etc). If the contextual meaning is undertood non-literally, then the unit is marked as metaphorical. Please see Gerard, Aletta, Herrmann, Kaal, Krennmayr, \& Pasma (2010) for further details.

As verbs take crucial roles here, data driven examination, particularly the affix formation, is required before the metaphor classification begins. It is also important to understand what metaphor classes and semantic prosodies are present for the victory verbs in Indonesian.

Besides the metaphor class, I also investigate whether the prosody is affected by the semantic role of the argument. The classification of the roles here follows Saeed (2009) who distinguished between 〈theme> and 〈patient>. In this study, this distinction is useful to investigate whether certain verbs have the tendency to license certain arguments. The procedures of data collection and analysis are described as follow:

(1) Football news articles from different news portal repositories (http://sport.detik.com/, http://bola.okezone.com/, http://tabloidbola.com, http://www.juara.net/, http://www.goal.com/id-ID ) were retrieved, but only articles with victorious verbs were selected; the texts were built as a text corpus (1507 tokens in total)

(2) Victory verbs used in these texts were identified along with their affix formation.

(3) The verbs were categorized based on their metaphor classes (see Metaphor Identification Procedure that has been commented on previously).

(4) Prosodies and semantic roles were assigned to each verb 
(5) Whether the semantic role of the argument correlates to the prosody was investigated

\section{FINDINGS AND DISCUSSION}

\section{A. Affix formation}

Affix formation in the data is divided as follows: $\{\mathrm{meN}-\},\{\mathrm{meN}-\mathrm{i}\},\{\mathrm{meN}$ kan\}, \{meN-peR\} and \{meN-peR-kan\}. There are five patterns in total and table 1 summarizes them:

Table 1:

Affix Formation

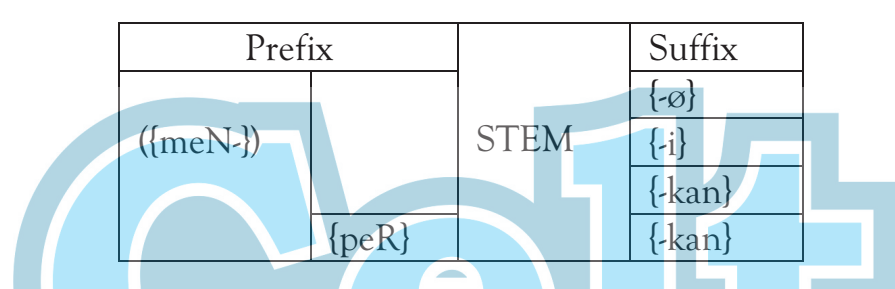

Prefix meN- seems to be obligatory, but not when they are in the form of headline. Contrasting examples are in (3) and (4):

(3) Cetak Kemenangan ke-Tiga, Madrid naik ke Puncak Klasemen Sementara

'Print the third winnings; Madrid goes on top of the league'

(4) Juventus mencetak kemenangan perdana di laga pembuka Lega Calcio

'Juventus printed the first victory in the opening match of Lega Calcio'

Example (3) is a headline, while example (5) is taken from an article in the body text. Prefix $\left\{\mathrm{meN}_{-}\right\}$is not present in (1) but present in (2). These two sentences are totally acceptable in Indonesian. As attested in Alwi, Dardjowidjojo, Lapoliwa, \& Moeliono (1998), prefix $\left\{\mathrm{meN}_{-}\right\}$is not obligatory in Indonesian, but it functions as formal domain marker. In this football text collection, it becomes a distinctive feature of headlines. When this fact is taken into consideration, the number of the patterns can multiply from 5 to 10 and $\{\mathrm{meN}-\}$ is considered optional. There are several functions of suffix $\{-\mathrm{i}\}$ and $\{-$ kan\}, but in the data they are used to mark transitive verbs. Prefix \{per-\} is a verbalizer that derive verbs from adjectives. 
Not all stems can be attached to any affix(es). Sufix $\{-\mathrm{i}\}$ attaches to menang 'to win', sudah 'to finish', unggul 'to advance', genap 'to be even (as in even number), gundul 'to be bald' and pecundang 'a loser'. Without the presence of the suffix, or the attachment to the wrong suffix, these words might sound odd, unnatural (?), or wrong $\left(^{*}\right)$.

(5) Brazil meng-gundul-i Polandia 4-0

'Brazil shaved bald Poland 4-0'

(6) Brazil gundul-i Polandia 4-0

(7) Brazil menggundul-kan? Polandia 4-0

(8) Brazil gundul-kan? Polandia 4-

(9) Brazil meng-gundul-ø* Polandia 4-0

(10) Brazil gundul-ø * Polandia 4-0

The stem gundul means to shave bald. Example (5) to (10) shows both licensed and unlicensed affix formation. This valence is unique to gundul and does not necessary apply to other verbs. Each verb has a unique valence that license some prefixes (un) attachable to it.

Now, consider some stems that must take suffix \{-kan\}: singkir 'to get rid', tunduk 'to make someone nod down', hancur 'to destroy', takluk 'to subjugate', jinak 'to domesticate'. There is one stem, malu 'to be embarassed' which has to take simulfix \{peR-kan\}. Example (11) to (12) show licensed and unlicensed affixes for malu, 'to embarrass':

Napoli mempermalu-ø ${ }^{*}$ Inter di kandang sendiri

'Napoli embarrassed Inter on their home stadium'

(11) Napoli malu-kan* Inter di kandang sendiri

(12) Napoli mem-per-malu-kan Inter di kandang sendiri

However, stems taking obligatory simulfix are not many. Another verb that licenses simulfix is tahan 'to hold', which takes \{peR-kan\} simulfix, resulting in pertahankan. The configuration of this stem is just like malu, where the absence of one of the affixes makes the word unacceptable in Indonesian. 
(13) Persipura berhasil pertahan-ø * piala liga Indonesia

'Persipura has managed to maintain the Indonesian league cup'

(14) Persipura berhasil tahan-kan * piala liga Indonesia

(15) Persipura berhasil mem-per-tahan-kan piala liga Indonesia

Prefix \{peR-\} is obligatory only to one adjective stem, which is panjang 'to be long'. Unlike gundul, this stem cannot take $\{-i\}$ suffixes. Consider (16) to (18);

(16) Barcelona per-panjang rekor kemenangan di kandang lawan

Barcelona extended the winning record in the enemy's field.

(17) Barcelona panjang-kan rekor kemenangan di kandang lawan

(18) Barcelona panjang-i* rekor kemenangan di kandang lawan

\section{B. Semantic roles: 〈gent>, 〈benefactor>, 〈theme> and <patient>}

The team, which wins a match or a championship, is referred as the victor, while the loser will be referred as the defeated (team). The semantic role of the victor here is as an 〈agent>, responsible for the victory to happen. Frequently, the <agent> slot is filled with the name of the winning team like Barcelona/Barca, Real Madrid/Madrid, Manchester United/MU and etc. However, besides its official team name, a team is sometimes addressed by different referring expressions. See (19) where Argentina Team is referred as Tim Tango 'Tango Team', and (20) where Manchester United is referred as Setan Merah 'red devil':

(19) Tango Menggilas Bolivia Dengan Skor Telak 5-0

Tango grinded down Bolivia with a large score gap of 5-0

(20) Setan Merah berhasil mengalahkan rival abadinya The Gunners

The Red Devil has managed to defeat The Gunners, their eternal rival

Victory can be defined in terms of a match, or a series of matches in a championship. On (21) we can see that the victor is Real Madrid in a match against Deportivo. In (22) however, the defeated team is not mentioned, but it clearly suggests that Borussia Dortmund has just finished the race of the league 
championship by being in the first position, which is a winner of a series of matches (a competition).

(21) Real Madrid mengalahkan Deportivo 2-0

Real Madrid defeated Deportivo 2-0

(22) Borussia Dortmund kembali merengkuh titel Bundesliga Jerman musim ini

Borussia Dortmund grabbedthe Bundesliga title again this season

A victor can not only be represented by the name of the team orcountry (e.g. Juventus, Parma, Brazil, Japan) or by one of the members of the team. See (23) where Arjen Robben defeated Hungaria. The reference of Arjen Robben is part-of-a-whole relation. This means the one who defeated Hungaria is not Arjen Robben himself, but along with all the team members of the Dutch team. In this case, the use of the player's name, coach, manager or someone related to the victor is to highlight his/her significant role to the victory. The same applies to (24):

(23) Arjen Robben Sukses Menggunduli Hungaria Dengan Skor 8-1

'Arjen Robben successfully shaved bald Hungaria 8-1'

(24) Gol Van Persie ke gawang klub asal Yunani itu membawa Fenerbahce menang 10

Van Persie's goal to the Greece origin club has brought Fenerbache victory $1-0$

The optional slot to fill either the team or one of its members allows the restriction of the noun to both animate (human) and inanimate (team) noun. Besides the team member, the team is sometimes addressed to the relation to their homebase: tim tamu 'away team' or tim kandang 'home team'.

Consider (25), where it was actually a match between Persibo Bojonegoro and Bontang FC that ended in Persibo's victory. In (26), the defeated team is not referred as Bontang FC, but by tim tamu as they were the away team. Note also the last discussed pattern, where a member of the team may represent the team as a whole. We see Syamsul Arif in (26) takes the slot of <agent> instead of his team Persibo Bojonegoro.

(25) Syamsul Arif berhasil mempecundangi tim tamu dengan skor 4-2 
'Syamsul Arif has managed to make the away team lose with 4-2'

(26) Yossi Benayoun memberikan kemenangan untuk Liverpool

\section{'Yossi Benayoun gave winnings for Liverpool'}

The winning team is not explicitly mentioned in (25), therefore the presence of anaphoric resolution in the text, or the background knowledge that a player is a member of a team is necessary. Example (26) is different as the winning team, Liverpool, is mentioned. In this case, the winning team might take the slot of the <benefactor $>$.

While the role of the argument in subject position is already clear as the <agent>, the role of the object must be discussed further. Nouns in the object position are usually the defeated team, or the victory itself (of a match, title, champion, record etc). Hence, the arguments in object position can be divided into two categories based on the predicate-argument framework. The first category is the argument that undergoes a change of state. The second one is the argument that does not undergo a change of state, but the verb indicates that there is a possession transfer.

(27) Mancester City akhirnya meraih gelar juara Liga Inggris

Manchester City has finally reached the title of the League

(28) Timnya bakal mampu mencuri kemenangan

The team will be able to steal a victory

(29) Jakarta merebut gelar juara Liga Futsal Perindo

Jakarta took over the title of Perindo Futsal League by force

(30) Tim Tango Menggilas Bolivia Dengan Skor Telak 5-0

Tango Team grinded down Bolovia 5-0

(31) Real Madrid menghancurkan Granada

Real Madrid destroyed Granada

(32) Persib U-21 akhirnya menekuk juara bertahan Pelita Jaya 2-0

Persib U-21 has finally folded the previous champion, Pelita Jaya 2-0 
There is no state of change identified for the object position argument in (27) to (29). What happened is the transfer of champion title gelar juara (27 and 29) and victory kemenangan (28) to the direction of the winning team as specified by the verb meraih 'to obtain', mencuri 'to steal' and merebut 'to take over' respectively. As for (30) to (32), the nouns undergo a change of state as specified by the verb menggilas 'to grind', menghancurkan 'to destroy', and menekuk 'to fold'. The arguments are all for the defeated teams. In literal nonassociative meaning, arguments specified by these verbs (menggilas, menghancurkan) are usually solid inanimate entities or two dimensional entities when specified by menekuk. When used in football domains, the semantic features of the inanimacy or the 2-dimensions are transferred to the defeated teams, making the violation of selectional restriction acceptable.

It can be summarized that the victor may take the role as either an <agent> or a <benefactor>, while a member of the team always takes the role as an 〈agent>. Both the victor and a member of the winning team take the subject position.

\section{Metaphor Classes and Semantic Prosody}

+ AMOUNT

Victory verbs +AMOUNT deal with verbs indicating an increase or decrease in amount. It might be the number of the winnings, or the number of goals. At this point, VICTORY is MATH, where the concept of subtractions and additions are adopted. See table 2:

Table 2:

+ AMOUNT CLASS

\begin{tabular}{lllll}
\hline Sub Class & lemma & affix & word & Gloss \\
\hline Increase & panjang & meN-per- & memperpanjang & to extend \\
Increase & genap & meN-i & menggenapi & to make even \\
Increase & kumpul & meN-kan & mengumpulkan & to accumulate \\
Increase & lanjut & meN-kan & melanjutkan & to continue \\
Increase & ganda & meN-kan & menggandakan & to double \\
Decrease & sisih & meN-kan & menyisihkan & to subtract \\
Decrease & singkir & meN-kan & menyingkirkan & to get rid \\
\hline
\end{tabular}


The term increase deals with how the winning teams add victory/ies to their records, as reflected by memperpanjang 'to extend' and melanjutkan 'to continue' As for the word mengumpulkan 'to accumulate', it might describe victories as a group. The word menggenapi 'to make even' is a little bit different, because it does not directly refer to the victory or the number of the goal. It describes a victory, where the last goal scored by a player is highlighted. For this reason, although genap literally means odd (as opposed to 'even' number), odd and even scores are both acceptable. See example (33) and (34) where the same team, Arsenal (or the Gunner) won the match 3-0 and 4-1. As for menggandakan 'to double' the score is always 2 for the victor. This is interesting as it does not apply to the other two-folds. See (35):

(33) ia mampu menceploskan bola untuk menggenapi kemenangan The Gunners malam itu 3-0

'he managed to score, completing the Gunner's victory 3-0'

(34) Dan akhirnya Giroud menggenapi kemenangan Arsenal menjadi 4-1

And finally, Giroud completed Arsenal's victory 4-1

(35) Mantan bintang Liverpool, Luis Suarez, menggandakan kemenangan Barcelona menjadi 2-0 'ex-Liverpool star, Luis Suarez, doubled Barcelona's Victory 2-0

The term decrease deals with how the victors take the chance of winning from the defeated team. It is shown by words menyisihkan 'to subtract' and menyingkirkan 'to get rid', which collocate with the name of the defeated team as in (36) and (37).

(36) klub Jerman yang menyisihkan Inter Milan di perempatfinal

'the German club that substratced Inter Milan in quarter final'

(37) Keberhasilan Barcelona menyingkirkan AC Milan

'Barcelona success in getting rid of AC Milan'

\section{+BODY PARTS}

Among the classes of metaphorical expressions, +BODY PARTS substantially dominates. The fact that + BODY PARTS are often used in metaphors is 
attested in Deignan (2006), Lingzhi (2007) and Yu (2008). This class is divided into four sub-classes: hand, head, foot and mouth. Among these, hand mostly vary with 10 different types. The rest are represented by one word each:

Table 3:

+BODY PARTS CLASS

\begin{tabular}{lllll}
\hline Sub Class & Lemma & Affix & Word & Gloss \\
\hline Hand & rengkuh & meN- & Merengkuh & to embrace sth \\
Hand & gondol & meN- & menggondol & to steal \\
Hand & bawa & meN- & Membawa & to carry \\
Hand & genggam & meN- & menggenggam & to hold \\
Hand & raih & meN- & Meraih & to reach \\
Hand & rebut & meN- & Merebut & to take over with force \\
Hand & tekuk & meN- & Menekuk & to fold \\
Hand & angkat & meN- & mengangkat & to lift \\
Hand & cukur & meN- & Mencukur & to shave \\
Hand & gundul & meN-i & menggunduli & to shave bald \\
Foot & jegal & meN- & Menjegal & to use your foot to stumble \\
& & & block other's foot so that \\
Mouth & bungkam & meN- & membungkam & to not talk \\
Head & tunduk & meN-kan & menundukan & to make someone/sth nod \\
\hline
\end{tabular}

Foot and mouth are represented by only one word each, menjegal and membungkam. These two words are negative in polarity. Menjegal means to make someone stumble, and membungkam means to shut one's mouth. Head is also represented by menundukkan. This word means to make someone's head nod down, where the victor successfully subjugates the defeated.

The next sub-classes are mencukur and menggunduli where both of them are related to shaving activities. This sub-class is interesting as hand (self) interacts with head (another). I include these words under the coloumn "Su blcass as "hand" as the role of hand is more active and dominant here, while head is the object. 
While mencukur 'to trim' still leaves some of the existing hair, menggunduli 'to shave bald' is an activity of shaving head that leaves no hair. The baldness here at first seems to reflect zero-goals scored by the defeated team. However, this may apply to non-zero score from the defeated teams as well. Therefore, whether or not the defeated team was able to score there is a score gap present between the victor and the defeated. See (38) - (41):

(38) Argentina mempermalukan paraguay dengan mencukurnya dengan skor $6-1$

'Argentina embarrassed Paraguay by trimming it 6-1'

(39) Bayern Muenchen mencukur Hamburg 8-0

'Bayern Muenchen trimmed Hamburg 8-0'

(40) Arjen Robben Sukses Menggunduli Hungaria dengan Skor 8-1

'Arjen Robben successfully shaved bald Hungaria 8-1'

(41) Thailand menggunduli tim Indonesia 7-0

'Thailand shaved bald Indonesian team 7-0'

Other body parts are also used, such as foot menjegal, mouth membungkam, and menundukkan. However, they are more or less dominant than hand, which is only has one lemma for each sub-class.

(42) Persipura Jayapura ingin membungkam Persiram Raja Ampat

'Persipura Jayapura wanted to shut-the mouth of Persiram Raja

Ampat-down'

(43) Barca sukses menjegal Madrid

'Barcelona successfully stumbled down Madrid'

\section{+ EMOTION}

Some verbs have the effect on the emotional state of the experiencer, which is the emotional reaction that the experiencer has (Langacker, 2011). In the data, I identified mempermalukan 'to humiliate', a verb requiring an object, where in this data, the defeated team experiences humiliation from the victor. 
192 Celt, Volume 15, Number 2, December 2015, pp. 178-204

The verb mempermalukan 'to embarrass', is placed under the +EMOTION class. Focus on (44) and (45):

Table 4:

+ EMOTION Class

\begin{tabular}{lllll}
\hline Sub Class & Stem & Affix & Word & Gloss \\
\hline COGNITION & malu & meN-per-kan & mempermalukan & to \\
& & & & embarrass \\
& & & \\
& & & & \\
& & &
\end{tabular}

(44) Palermo sukses mempermalukan Roma dihadapan publik sendiri Palermo successfully embarrassed Roma on their home turf

(45) Lazio mempermalukan Filippo Inzaghi dengan skor tipis 0-1 di San Siro

Lazio embarrassed Filippo Inzaghi with thin score 0-0 in San Siro

Example (45) is interesting as it is uncommon for Fillipo Inzaghi (AC Milan's coach, a member of the team, to represent the defeated team, AC Milan here. A member of the team might usually replace the team when it takes the role of an <agent> (as it has been commented previously).

\section{+COMPETITION}

Verbs that fall under the category of +COMPETITION are very productive in frequency although it only comprises of four words: mengalahkan 'to defeat', memenangi 'to win', mempecundangi 'to defeat', and mengungguli 'to advance'. Among these, mengalahkan and memenangi are the most productive.

Table 5:

+ COMPETITION Class

\begin{tabular}{lllll}
\hline Class & Stem & Affix & Word & Gloss \\
\hline & & meN- & & to make someone/sth \\
competition & kalah & kan & Mengalahkan & lost \\
competition & menang & meN-i & Memenangi & to win over \\
\hline
\end{tabular}




\begin{tabular}{lllll}
\hline & & & & someone/sth \\
& Pecun- & & Mempecun- & to make someone/sth \\
competition & dang & meN-i & dangi & a loser \\
competition & unggul & meN-i & Mengungguli & to advance over sth \\
\hline
\end{tabular}

(46) Real Madrid mengalahkan Deportivo 2-0

'Real Madrid made Deportivo lose 2-0'

(47) Barcelona memenangi pertandingan itu dengan skor 2-1

'Barcelona won the game 2-1'

(48) Perseba Super mempecundangi Purwanto dkk 1-0

Perseba Super made Purwanto and friends lose 1-0

(49) namun Arema akhirnya sukses mengungguli tim tamu

but Arema finally succeeded in advancing the away team

+ CREATION and +DESTRUCTION

The metaphor class of +CREATION and +DESTRUCTION suggests the change of state of the argument. +CREATION is represented by only one verb membungkus 'to wrap', while the +DESTRUCTION is represented by menggilas 'to grind sth down', menghancurkan 'to destroy sth' and meruntuhkan 'to collapse down'. <Patient>s of the verbs are usually solid inanimate entities, but specific to a tree for menumbangkan.

Table 6:

+ CREATION and +DESTRUCTION Classes

\begin{tabular}{lllll}
\hline CLASS & Stem & Affix & Word & Gloss \\
\hline Destruction & gilas & meN- & menggilas & to crush over sth \\
Destruction & hancur & meN-kan & menghancurkan & to destroy sth \\
Destruction & runtuh & meN-kan & meruntuhkan & to collapse sth down \\
Destruction & tumbang & meN-kan & menumbangkan & to cut (a tree) down \\
Creation & bungkus & meN- & membungkus & to wrap sth \\
\hline
\end{tabular}


194 Celt, Volume 15, Number 2, December 2015, pp. 178-204

The verb membungkus however, does not suggest that the entity's basic shape has changed. It implies that the entity is covered by something so that the original shape is hidden. As for the words under +DESTRUCTION class, the basic shape of the entity has undergone changes.

(50) Tim Tango Menggilas Bolivia Dengan Skor Telak 5-0

'Tango team crushed downBilivia 5-0'

(51) Real Madrid menghancurkan Granada

'Real Madrid destroyed Granada'

(52) Akankah AS Roma dan AC Milan mampu meruntuhkan dominasi Juventus?

Will AS Roma and AC Milan can collapse down Juventus domination?'

(53) Arema menumbangkan PSM Makassar 2-0

Arema cutdown PSM Makassar 2-0

(54) Madrid membungkus hasil sempurna dari tiga kali berlaga Madrid wrapped perfect results of three matches

+CONFLICT: +CRIME, +WAR and +FIGHT

As described by some previous studies, Bergh (2011) and Charteris-Black (2004), the use of +WAR metaphorsare a common phenomenon in sports especially in the football domain. This is attested also by the data, with other two similar sub-classes, +CRIME and +WAR. Together, they are placed under +CONFLICT class, where they share one common feature: aggression.

The verbs that belong to the category of +WAR, +FIGHT and +CRIME, are actually not used very frequently. However, the pattern of metaphors is unique as victory is something good but the way it is obtained, as reflected by the verbs, is described as something negative.

This goes to all verbs, except mempertahankan 'to maintain', which is positive in meaning. See table 7: 
Table 7:

+CRIME, +WAR and +FIGHT Classes

\begin{tabular}{|c|c|c|c|c|}
\hline $\begin{array}{l}\text { Sub- } \\
\text { Class }\end{array}$ & Stem & Affix & Word & Gloss \\
\hline Crime & Curi & meN- & Mencuri & to steal \\
\hline Crime & bobol & meN- & Membobol & $\begin{array}{l}\text { to break through } \\
\text { to arrest }(\mathrm{a}\end{array}$ \\
\hline Crime & bekuk & meN. & membekuk & $\begin{array}{l}\text { criminal) } \\
\text { to destroy with }\end{array}$ \\
\hline War & ganyang & meN- & mengganyang & excessive force \\
\hline War & takluk & $\begin{array}{l}\text { meN-kan } \\
\text { meN-per- }\end{array}$ & menaklukan & to conquer \\
\hline War & tahan & kan & mempertahankan & $\begin{array}{l}\text { to maintain } \\
\text { to destroy sth }\end{array}$ \\
\hline War & bumihangus & meN-kan & membumihanguska & $\begin{array}{l}\text { totally } \\
\text { to physically hurt }\end{array}$ \\
\hline Fight & najar & & menghajar & someon \\
\hline Fight & gebuk & meN- & menggebuk & to smack \\
\hline
\end{tabular}

Mencuri 'to steal' and membobol 'to break' (as in breaking and entering) are verbs where the inherent lexical features already suggest a crime. The verb membekuk 'to arrests' also specifies a criminal. The +WAR verbs mengganyang and menaklukkan, are all simple verbs used specifically to describe the destruction in a war. Of the verb stems presented on table 7 , one is a compound, which is bumi hangus. The compound bumi 'Earth' and hangus 'overburn' is an expression used in war to indicate an action of total attack leaving not even a single enemy alive or single building standing. That means every enemy must be killed, and every buildings must be burned down. The <patient>s of the verbs under the category of +FIGHT are usually human such as menghajar 'to hurt' and menggebuk 'to smack'. In this football domain, however, these verbs are used specificalyfor the defeated teams.

+ SCRIPT

Another metaphorical verb class to express victory is +SCRIPT. This verb includes membukukan 'to bundle (papers into a book), mencatat 'to write down', mencetak 'to print', and menorehkan 'to strike (a brush on a paper). 
196 Celt, Volume 15, Number 2, December 2015, pp. 178-204

What these verbs do is create a victory record parallel to the record in a form of written manuscript.

Table 8:

+SCRIPT

\begin{tabular}{lllll}
\hline CLASS & Stem & Affix & Word & Gloss \\
\hline script & buku & meN-kan & Membukukan & to bundle \\
script & catat & meN. & Mencatat & to write down \\
script & cetak & meN. & Mencetak & to print \\
script & toreh & meN-kan & Menorehkan & to strike (a brush) \\
\hline
\end{tabular}

The collocation of +SCRIPT verbs are all with kemenangan 'victory'. Please consider (55) to (58):

(55) Barcelona membukukan kemenangan besar 8-0 atas Cordoba

'Barcelona bundleddown a big victory against Cordoba 8-0'

(56) Inter mencatat 25 kemenangan, sembilan hasil imbang

'Inter noted 25 victories, nine draws'

(57) ...Setelah mencetak kemenangan 1-0, Advocaat masih...

'...after printing 1-0 win, Advocaat is still'...

(58) Persipura berhasil menorehkan kemenangan perdananya

'Persipura managed to stroke down their first winning'

+ TIME

There are two sub classes of +TIME, initial and end. The verb mengawali 'to begin' falls to the initial sub type, while menyudahi and menghentikan 'to finish' falls to end sub type. The first suggests that a victory has just begun. This does not seem to make sense at first as we cannot predict what is going to happen until the match ends. However, as the news reports past events, the use of this verb already indicates the victor of the game. 
Table 9:

+ TIME

\begin{tabular}{lllll}
\hline CLASS & Stem & Affix & Word & Gloss \\
\hline end & sudah & meN-i & Menyudahi & to finish \\
end & henti & meN-kan & menghentikan & to finish \\
Intial & Awal & meN-i & mengawali & To begin \\
\hline
\end{tabular}

(59) ...kesempatan bagus bagi Liverpool dalam menghentikan perlawanan The Gunners

'...a good chance for Liverpool to finish the gunner's resistence'

(60) ...Setelah menyudahi perlawanan Adelaide 1-0, mereka...

'...after finishing Adelaide's resistance 1-0, they...'

(61) Carlos Tevez mengawali kemenangan Juventus

'Carlos Tevez began the Juventus victory'

+ELEVATION

The verb menenggelamkan 'to sink down' might be one of the verbs that is infrequently used to indicate victory. It however is used although the verb is also used in war domains. When used to indicate something neutral, other words with equal meanings are usually used such as selam, celup, masukkan ke dalam air etc. When used in football domain, the victor is illustrated as stay afloat, while the defeated sinks down.

Table 10:

+ELEVATION Class

\begin{tabular}{lllll}
\hline Class & Stem & Affix & Word & Gloss \\
\hline Elevation & tenggelam & meN-kan & menenggelamkan & to sink \\
\hline
\end{tabular}

(62) Didepan publiknya, Cina menenggelamkan Indonesia lima gol

'In front of their public, China sank down Indonesia five goals' 


\section{+DOMESTICATION}

The use of the verb menjinakkan 'to tame' is specific to wild animal, therefore is a violation to selectional restriction. As it has been discussed by Molinaro, Carreiras, \& Duñabeitia (2012) and Friederici \& Weissenborn (2007), this is anomalous clause. One that can domesticate must have the feature of a human, and the object tamed must have the feature of an animal. The defeated team here, the <patient>, is illustrated as a wild animal, and has to be domesticated. When the wild animal is defeated then the <agent $>$ taming the animal is the victor.

Table 11:

+DOMESTICATION Class

\begin{tabular}{lllll}
\hline Class & Stem & Affix & Word & Gloss \\
\hline Domestication & jinak & meN-kan & menjinakkan & to tame (an animal) \\
\hline
\end{tabular}

(63) The Blues menjinakkan tuan rumah West Brom 3-2

'the Blues tamed the home team West Brown 3-2'

+TRANSFER

As it has been discussed by Saeed (2009), transfer verbs, like "give", indicate a transfer from one entity to another. Unlike other verbs discussed for metaphorical verbs, the agent transfer verb memberi 'to give' is always a person, usually the player. A victory is given by a person to his/her team. The person can be the player, the referee, the coach, or even the player from the opponent team. See (65) where an own goal from the opponent team gave a victory to Manchester United. The position of <theme> and <benefactor> can be swapped. See (65 and 66) where the <benefactor>, Manchester United, and the $\langle$ theme>, Kemenangan, can be swapped. It therefore justifies the transfer verb beri as two arguments verb.

Table 12:

+ TRANSFER Class

\begin{tabular}{lllll}
\hline Class & Stem & Affix & Word & Gloss \\
\hline transfer & beri & meN. & memberi & to give \\
\hline
\end{tabular}


(64) Yossi Benayoun yang memberikan kemenangan untuk Liverpool

'Yossi Benayoun gave a victory for Liverpool'

(65) Gol Bunuh Diri Dari Kyle Walker Memberi Manchester United Kemenangan

'Kyle Walker's own goal gave Manchester United a victory'

(66) Gol Bunuh Diri Dari Kyle Walker Memberi Kemenangan pada Manchester United

'Kyle Walker's own goal gave a victory to Manchester United

\section{Semantic prosody}

The semantic prosody of the verbs here is divided into three: negative, neutral, and positive. Verbs carrying negative semantic prosody are observed at the number of 22, while there are 24 verbs carrying neutral semantic prosody. Verbs carrying positive semantic prosody are the least, which are only four verbs.

Most of the verbs carrying negative semantic prosodies come from +CONFLICT metaphor classes, such as +WAR membumihanguskan 'to totally destruct something', mengganyang 'to destroy with excessive force', and menggebuk 'to smack' etc. However, there are some verbs from other classes as well such as +DOMESTICATION menjinakkan 'to tame/domesticate', +EMOTION mempermalukan 'to embarrass', or the class which at the surface seems to be neutral like +BODYPARTS. Consider menjegal 'to use your foot to block another's foot so that s/he will fall', and membungkam 'to shut one's mouth':

Table 13:

Negative Semantic Prosody Verbs

\begin{tabular}{ll|ll}
\hline Verb & Gloss & Verb & Gloss \\
\hline menenggelamkan & to sink & Mempecundangi & to win over sth \\
meruntuhkan & to ruin down & Menjegal & to use your foot to \\
& & $\begin{array}{l}\text { block other's foot } \\
\text { so that s/he will } \\
\text { fall }\end{array}$ \\
\hline
\end{tabular}




\begin{tabular}{|c|c|c|c|}
\hline membumihanguskan & $\begin{array}{l}\text { to destroy sth } \\
\text { totally }\end{array}$ & Mencuri & to steal \\
\hline menghajar & $\begin{array}{l}\text { to physically hurt } \\
\text { someone }\end{array}$ & Membobol & to break through \\
\hline membungkam & to not talk & Menggilas & to crush over \\
\hline menumbangkan & to fall & Menghancurkan & to destroy \\
\hline \multirow[t]{2}{*}{ menggebuk } & to smack & Menggondol & to steal \\
\hline & & Mengganyang & $\begin{array}{l}\text { to destroy with } \\
\text { excessive force }\end{array}$ \\
\hline memukul & to hit & Menaklukan & to conquer \\
\hline menundukan & $\begin{array}{l}\text { to make } \\
\text { someone/sth nod }\end{array}$ & Merebut & $\begin{array}{l}\text { to take over with } \\
\text { force }\end{array}$ \\
\hline mempermalukan & to embarrass & Menjinakkan & to tame \\
\hline
\end{tabular}

In contrast to negative semantic prosody verbs, there are only four types of positive polarity verbs. Most of the verbs are +COMPETITION class, but there is one positive semantic prosody verb from +WAR sub class, which is mempertahankan.

Table 14:

Positive Semantic Prosody Words

\begin{tabular}{ll}
\hline Verb & Gloss \\
Memenangi & to win over sth \\
Mengalahkan & To defeat \\
Mengungguli & to advance over sth \\
Mempertahankan & to maintain \\
\hline
\end{tabular}

Although it is not absolute, negatively associated classes might lead to negative semantic prosody. The unparallel distribution between class and prosody might be driven by the fact that some verbs might take the feature of more than one class. Consider menggondol which is classified as +BODYPART. It refers to the activity of carrying stolen goods (by hand). This meaning also suggests that it can actually also be classified into +CRIME class. See (67), where the prosody is positive, as contrasted to (68), where the prosody is negative. If we consider the collocate of the <agent> of menggondol can also be 
an animal. One that is frequently used is a cat as in (69), where the prosody is negative:

(67) Madrid kembali menggondol piala liga champion

Again, Madrid carriedthe stolen champion league cup

(68) Maling itu menggondol sebuah TV LED dan satu unit PC

The thief carried an LED TV and a PC

(69) Jangan biarkan kucing itu menggondol ikan kita lagi

Do not let the cat steal and carry our fish away again.

There are two structures of semantic roles. The first one is $\mathrm{V}$ (<agent>, $<$ theme $><$ benefactor $>$ ) and the second one is $\mathrm{V}$ (<agent $\rangle$, <patient $>$ ). The role of $\langle$ agent $>$ is usually assigned for the victor or its member. As for $<$ patient $>$, the defeated teams dominate this role. The role of $\langle$ theme $>$ on the other hand is filled with the victor's achievement like title, championship, cup and etc.

When we link semantic prosody to semantic role, there is a tendency for arguments that take the slot of a $\langle$ patient $\rangle$ to collocate with negative prosody verbs. Consider the statistic for $\langle$ theme $>(P o s=1 / \mathrm{Neu}=11 / \mathrm{Neg}=4)$ and patient $(\mathrm{Pos}=3, \mathrm{Neu}=13 / \mathrm{Neg}=16)$. The proportion of negative prosody verbs for <patient> is more than that of a <theme>. As it has been commented previously, a <patient $>$ is different from a <theme $>$ as it undergoes a change of state. One reason why the <theme> has less tendency to collocate to negative semantic prosody is because, only transfer of possession takes place. The state of the argument remains intact.

\section{CONCLUSION}

Although not absolute, in this study, I have discovered that metaphor type and argument type is influential toward negative/positive prosody. I here have managed to identify 10 metaphor classes of football victory verbs used in Indonesian news portals, which are +AMOUNT, +BODY PARTS, + COGNITION, +COMPETITION, +CREATION \& DESTRUCTION, +CONFLICT, +SCRIPT, +TIME, +DOMESTICATION, and +TRANSFER. There is a tendency for some classes to have negative prosody verbs, such as + DESTRUCTION or +CONFLICT. However, negative semantic prosody is 
also discovered from metaphor classes which seemed neutral (e.g menjegal 'to use your foot to stumble block other's foot so that s/he will fall' which is under the category of +BODY PARTS).

Several roles are identified from analyzing arguments in the data in this study. The victors, most of the time, are <agent>s. It may take the role of <benefactor>, but the number is not significant and only applies when the referring expression is a team member instead of the team. On object position, the arguments are either <theme> (victory, title, record) or <patient> (the defeated team). When arguments take the role of $\langle$ patient $\rangle$, the semantic prosody of the verb is mostly negative as shown by the statistics.

Although there is a strong tendency for metaphor class and argument type to positively correlate to prosody assigning, exceptions and irregularities in this data show us that we need to reexamine the data on the terminal level for the reason that each word (verb in this study) has a unique valence. The valence does not only license affixes and syntactic structure, but also the argument's semantic and prosody.

\section{REFERENCES}

Adriani, M., \& Hamam, R. (2009). Research Report Phase 3.2: Final Report on Statistical Machine Translation for Bahasa Indonesia - English and English to Bahasa Indonesia. Jakarta: BPPT.

Alwi, H., Dardjowidjojo, S., Lapoliwa, H., \& Moeliono, M. (1998). Tata Bahasa Baku Bahasa Indonesia (3rd Edition). Jakarta: Balai Pustaka.

Bergh, G. (2011). Football is War: A Case Study of Minute-by-Minute Football Commentary. Veredas on line-Tematica, 2, pp. 83-93.

Bergh, G., \& Ohlander, S. (2012). Free kicks, dribblers and WAGs. Exploring the language of "the people's game". Moderna språk, 106 (1), pp. 11-46.

Charteris-Black, J. (2004). Corpus Approach to Critical Metaphor Analysis. New York: Palgrave-MacMillan.

Deignan, A. (2006). Metaphor and Corpus Linguistics. Amsterdam/Philadephia: John Benjamins. 
Friederici, A.-D., \& Weissenborn, J. (2007). Mapping sentence form onto meaning: The syntax-semantic interface. Brain research, pp. 50-58.

Gerard, J.-S., Aletta, G.-D., Herrmann, J.-B., Kaal, A.-A., Krennmayr, T., \& Pasma, T. (2010). A Method for Linguistic Metaphor Identification. Amsterdam/ Philadelphia: John Benjamins.

Hunston, S. (2007). Semantic Prosody Revisited. International Journal of Corpus Linguistics 12 (2), pp. 249-268.

Khairina, R. (2012). Analisis perbandingan metafora dalam artikel sepakola pada tabloid 'Bola' Indonesia dan 'Kicker' Jerman. An unpublished bachelor thesis. Depok: UI.

Kovesces, Z. (2010). Metaphor. Oxford: Oxford University Press.

Langacker, R.-D. (2011). On the subject of impersonals. In M. Brdar, S.-T. Gries, \& I.-C. Fuchs (Eds.) Cognitive linguistics: convergence and expansion, 32, (pp. 179-216). Philadelphia/Amsterdam: John Benjamins Publishing.

Lestari, T.-P. (2013). Disfemia dalam Berita Sepakbola Nasional. An unpublished bachelor thesis. Yogyakarta: UNY.

Lewandowski, M. (2012). The language of online sports commentary in a comparative perspective. Lingua Posnaniensis, 54 (1), pp. 65-76.

Lewandowski, M. (2012). Football is not only war. Non-violence conceptual metaphors in English and Polish soccer language. Retrieved from Adam Mickewics University Academia: https://amu.academia.edu/Marcin Lewandowski

Lewandowski, M. (2009, April). Metaphors from Other Sports in the Language of Soccer - Evidence from English and Polish. Retrieved March 6, 2015 from Repozytorium Uniwersytetu im. Adama Mickiewicza (AMUR): https://repozytorium. amu.edu.pl/jspui/ handle/10593/4495

Lingzhi, T. (2007). The Metaphor of Parts of Human Body as Source Categories Metaphor [J]. Journal of Anyang Institute of Technology, 2 , 20 42 . 
204 Celt, Volume 15, Number 2, December 2015, pp. 178-204

Molinaro, N., Carreiras, M., \& Duñabeitia, J.-A. (2012). Semantic combinatorial processing of non-anomalous expressions, 59 (4). Neuroimage, pp. 3488-3501.

Prayogi, I. (2013). Metafora dalam berita sepakbola. Prosiding Seminar Internasional Pengembangan Bahasa dan Sastra Indonesia untuk Mewujudkan Pendidikan Berkarakter. Solo: UNS Press.

Prihantoro. (2015). The semantic prosody of words of effect in Indonesian. Indonesian Journal of Applied Linguistics, 5 (1), pp. 101-110.

Russel, G.-W. (2008). Aggression in the Sports World: A Social Psychological Perspective. Oxford: Oxford University Press.

Saeed, J.-I. (2009). Semantics. Cornwall: Blackwell Publishing.

Spandler, H., Roy, A., \& McKeown, M. (2014). Using football metaphor to engage men in therapeutic support. Journal of Social Work Practice, 28 (2), pp. 229-245.

Wardani, A. (2014). Metafora dalam berita olahraga superskor tabloid Tribun Yogya. An unpublished Bachelor thesis. Yogya: UNY.

Yu, N. (2008). The relationship between metaphor, body and culture. In T. Ziemke, J. Zlatev, \& M.-F. Roslyn. Body, Language and Mind, 2 (pp. 387 408). Berlin and New York: Mouton de Gruyter. 